\title{
Fire Blight Symptomatic Shoots and the Presence of Erwinia amylovora in Asymptomatic Apple Budwood
}

K. A. Tancos, E. Borejsza-Wysocka, and S. Kuehne, Department of Plant Pathology and Plant-Microbe Biology, New York State Agricultural Experiment Station, Cornell University, Geneva NY 14456; D. Breth, Cornell Cooperative Extension, Lake Ontario Fruit Program, Albion NY 14411; and Kerik D. Cox, Department of Plant Pathology and Plant-Microbe Biology, New York State Agricultural Experiment Station

\begin{abstract}
Erwinia amylovora, the causal agent of fire blight, causes considerable economic losses in young apple plantings in New York on a yearly basis. Nurseries make efforts to only use clean budwood for propagation, which is essential, but E. amylovora may be present in trees that appear to have no apparent fire blight symptoms at the time of collection. We hypothesized that the use of infected budwood, especially by commercial nursery operations, could be the cause, in part, of fire blight outbreaks that often occur in young apple plantings in New York. Our goal was to investigate the presence of E. amylovora in asymptomatic budwood from nursery source plantings as it relates to trees with fire blight symptoms. From 2012 to 2015, apple budwood was collected from two commercial budwood source plantings of 'Gala' and 'Topaz' at increasing distances from visually symptomatic trees. From these collections, internal contents of

apple buds were analyzed for the presence of E. amylovora. E. amylovora was detected in asymptomatic budwood in trees more than $20 \mathrm{~m}$ from trees with fire blight symptoms. In some seasons, there were significant $(P \leq 0.05)$ differences in the incidence of $E$. amylovora in asymptomatic budwood collected from symptomatic trees and those up to $20 \mathrm{~m}$ from them. In 2014 and 2015, the mean E. amylovora CFU per gram recovered from budwood in both the Gala and Topaz plantings were significantly lower in budwood collected $20 \mathrm{~m}$ from symptomatic trees. Further investigation of individual bud dissections revealed that $E$. amylovora was within the tissue beneath the bud scales containing the meristem. Results from the study highlight the shortcomings of current budwood collection practices and the need to better understand the factors that lead to the presence of E. amylovora in bud tissues to ensure the production of pathogen-free apple trees.
\end{abstract}

Fire blight, caused by the bacterium Erwinia amylovora, is responsible for devastating losses in plantings of apple (Malus $\times$ domestica Borkh.) worldwide (Vanneste 2000). In recent years, New York apple growers have experienced up to $50 \%$ tree losses in newly planted orchards due to sudden and unexpected fire blight following bloom (Breth 2008). Such losses will likely increase as older orchards are converted to high-density plantings consisting of highly susceptible apple varieties, which are planted to meet market demand (Breth 2008). Fire blight production losses occur in the form of direct reductions in harvestable fruit from blossom blight and fruit-bearing wood from shoot blight. Moreover, E. amylovora can spread systemically from blighted blossoms and blighted shoots to the central leader and rootstock of the tree, causing rootstock blight and, eventually, tree death (van der Zwet et al. 2012). Hence, management of blossom blight is essential to minimize direct losses as well as losses of whole trees. Presently, the aminoglycoside antibiotics streptomycin and kasugamycin are the most effective and widely used means of protecting apple blossoms from infection by E. amylovora (McGhee and Sundin 2011; McManus et al. 2002; Sundin 2014).

As infections progress into shoot tissues, it becomes difficult and labor intensive to control the spread of E. amylovora within the tree. Antibiotics such as streptomycin have limited systemic activity, making them ineffective when applied for shoot and rootstock blight. However, streptomycin is effective at reducing shoot blight when applied after trauma events that create bacterial entry points in green tissues (van der Zwet et al. 2012). The use of the growth regulator prohexadione-calcium has been shown to be effective in management of shoot blight because it causes thickening of the parenchymal cell walls, limiting the ability of the bacterial type-three pilus to deliver the effector proteins necessary for infection (McGrath et al. 2009). The thickening of cell walls further slows young, vigorous

Corresponding author: K. D. Cox; E-mail: kdc33@cornell.edu

Accepted for publication 21 August 2016.

C 2017 The American Phytopathological Society shoot growth, thereby reducing the amount of susceptible tissue available for infection (McGrath et al. 2009; Yoder et al. 1999). Once infection has become established, the only remaining control method is to prune out blighted shoot tissues. Removal of blighted shoots by cutting back into asymptomatic tissues of the previous year's shoot can reduce disease and prevent spread to other trees (Agnello et al. 2016).

Removal of blighted shoots, or strikes, typically occurs during winter and early spring pruning, or throughout the growing season as time permits. Pruning fire blight throughout the growing season is a common practice employed in nursery operations to ensure the production of pathogen-free planting material. It is recommended that fire blight strikes on nursery trees be removed as they appear throughout the period of terminal growth to minimize the spread of infection (Agnello et al. 2016). Although the removal of symptomatic tissues may reduce fire blight inoculum, it does not ensure the complete eradication of the pathogen from the tree. E. amylovora may persist as an endophyte within the tree and may not produce characteristic fire blight symptoms (Crepel and Maes 2000; Crepel et al. 1996; Ge and van der Zwet 1995, 1996; Keil and van der Zwet 1972; Momol et al. 1994, 1998; van der Zwet 1996). The occurrence of asymptomatic fire blight infection has been documented in several studies (Keil and van der Zwet 1972; McManus and Jones 1994; Smith 2002; van der Zwet 1983, 1996). In Washington State, Smith (2002) observed that nursery trees propagated with asymptomatic budwood led to the loss of nearly 50,000 trees over 3 years in one nursery. Such losses associated with asymptomatic budwood are especially disconcerting because new trees could remain symptomless for several years and be shipped to commercial orchards without knowledge of latent infections. Once planted in a commercial orchard, trees with such latent infections could develop symptoms during favorable weather and vigorous growth, and may lead to infection of nearby established trees and continued losses (Smith 2002; van der Zwet 1983, 1996).

Selection of pathogen-free budwood is essential to prevent the infection of newly propagated trees and the subsequent spread of E. amylovora to commercial orchards. The practice of selecting budwood varies across nursery operations but typically involves the collection of bud sticks from the current season's terminal growth in early fall. Nursery source collection ideally takes place in plantings 
that appear healthy and have no active fire blight symptoms (Agnello et al. 2016; Breth 2008). However, commercial demand for buds from certain cultivars with low availability may lead to relaxed selection practices. Additionally, the removal of shoot strikes throughout the season, a common management practice for fire blight, complicates collection of pathogen-free budwood due to the absence of characteristic fire blight symptoms, which may otherwise have been easily avoided. Hence, it is essential to keep a detailed record of fire blight occurrence in orchards used for nursery source materials.

The relationship of fire blight strikes and collection of infected budwood from the same tree has been studied (Smith 2002; van der Zwet 1996), although the presence and quantity of E. amylovora in the buds of asymptomatic trees has not been determined by any study to date. It is unknown whether surrounding symptomless trees are truly a reliable source of E. amylovora-free budwood. In order to better understand sudden and unexpected outbreaks of fire blight in young plantings in New York, we endeavored to investigate the relationship between position of symptomatic and asymptomatic trees, and the recovery of E. amylovora from budwood. The effect of apple cultivar on the presence of E. amylovora in budwood is also unknown and, in this regard, we examined asymptomatic buds of 'Topaz' and 'Gala' apple, both of which are susceptible to fire blight (Korba et al. 2008; Rosenberger 2003).

We hypothesize that asymptomatic trees located closer to symptomatic trees will have a greater incidence of E. amylovora in buds than those farther away from symptomatic trees. Furthermore, we hypothesize that different cultivars will differ in the incidence of E. amylovora in buds as it relates to proximity of fire blight symptoms. Regardless of whether these hypotheses are refuted or supported, the outcomes of this study should help to better explain the development of fire blight in young apple plantings in New York and further highlight the deficiencies in budwood collection practices with regard to the propagation of pathogen-free trees.

\section{Materials and Methods}

Collections of asymptomatic budwood. Over the course of four seasons from 2012 to 2015, budwood sticks were collected from two commercial apple orchards commonly used for nursery source material in Ontario County and Wayne County in western New York. The orchards were both planted to mature trees ( $>10$ years) growing at the site. The orchard in Ontario County was planted to Topaz apple on M.9 rootstocks, while the orchard in Wayne County was planted to Gala apple on M.9 rootstocks. Budwood collections took place following terminal bud set in late August to early September each year, with specific timing depending on the seasonal and local development of terminal buds. Prior to collection, orchards were observed for fire blight symptoms to determine spatial distribution of fire blight for the purpose of establishing sampling blocks with individual symptomatic trees. In each planting for each season, the orchard was divided into three replicate blocks and, within each of these, three individual trees with fire blight symptoms were designated as center points for budwood stick collection. Center-point trees had one to five shoot strikes and had an advanced necrotic brown to black appearance, with indications of one to four dried ooze droplets per strike. Trees in a radius of $50 \mathrm{~m}$ from the center-point tree were intensely scouted for fire blight symptoms to ensure that the centerpoint tree was the only visible fire blight source within the sampling block. Ten asymptomatic budwood sticks from the current season's growth, containing a minimum of five buds each, were randomly collected from three individual trees in the three replicate sampling blocks under three fire blight proximity ranges: (i) on the centerpoint trees (center-point; asymptomatic tissue on the symptomatic center-point tree), (ii) from branches on trees adjacent to a symptomatic center-point tree (adjacent; asymptomatic tree adjacent to the symptomatic center-point tree), and (iii) from trees more than $20 \mathrm{~m}$ away from a symptomatic center-point tree (>20 m; asymptomatic tree) (Fig. 1). Within replicate blocks, random selection of trees and shoots for collection was accomplished using polyhedral dice. Following collection, samples were packaged individually in plastic

bags, stored on ice, and immediately transported to the New York State Agricultural Experiment Station for processing.

Isolation and identification of $E$. amylovora from budwood. Budwood sticks were stored at $4^{\circ} \mathrm{C}$ in individual plastic bags for up to $48 \mathrm{~h}$. Prior to isolation of E. amylovora, five buds per budwood stick were removed and surface sterilized in a 5.25\% sodium hypochlorite solution by volume for $15 \mathrm{~min}$. Buds were rinsed three times with sterile water and transferred into a single $2.0-\mathrm{ml}$ microcentrifuge tube. A sterile steel bead and $1 \mathrm{ml}$ of $1 \times$ phosphate-buffered saline buffer were added to the tube and the tube was placed in a Tissuelyser (Qiagen Inc., Valencia, CA) for 2 min to grind samples. The macerated bud solution was then plated on Crosse Goodman media (CG) (Crosse and Goodman 1973) at appropriate dilutions for visual differentiation of single colonies and incubated at $28^{\circ} \mathrm{C}$ for $48 \mathrm{~h}$. The presence of E. amylovora colonies that displayed characteristic cratering morphology on CG was noted for each five-bud sample and used to calculate the incidence of infected budwood sticks for each replicate tree in the three proximity ranges. In 2014 and 2015, E. amylovora $\mathrm{CFU}$ were enumerated for collections made from both the Topaz and Gala orchards. Following morphological characterization, a subset of colonies with representation across all treatments, cultivars, and seasons was set aside and stored at $-80^{\circ} \mathrm{C}$ for subsequent molecular identification.

Localization of $\boldsymbol{E}$. amylovora within individual buds. To determine whether E. amylovora was present in the tissues containing the meristem or just in deep crevasses of bud scales, dissections were made from a subset of representative buds from all proximity ranges and both cultivars in 2012. In total, 18 intact buds were removed from budwood sticks, surface sterilized in a $15 \%$ Clorox solution for $15 \mathrm{~min}$, and subsequently rinsed three times with sterile water. Using sets of individual sterile dissection needles, individual bud scales were carefully removed with one needle per bud scale to separate the meristem tissue from the other tissues of the buds (Fig. 2). The tissues containing the meristem were then surface sterilized using the procedure above. The meristem tissue was then subjected to grinding, and the macerated meristem solution was subsequently plated on CG medium at appropriate dilutions for visual differentiation of single colonies as described above. After $48 \mathrm{~h}$ of incubation at $28^{\circ} \mathrm{C}$, colonies were observed for cratering morphology characteristic of E. amylovora. The colonies were then stored at $-80^{\circ} \mathrm{C}$ for subsequent molecular identification.

Polymerase chain reaction and sequencing confirmation of E. amylovora. The identity of putative E. amylovora colonies was confirmed by polymerase chain reaction (PCR) and sequencing of a portion of the ubiquitous nonconjugative plasmid pEA29, which has been shown to be reliable marker to confirm the identity of E. amylovora (Bereswill et al. 1992; Chiou and Jones 1993; McGhee and Jones 2000). Specifically, individual colonies were placed in $500 \mu \mathrm{l}$ of $\mathrm{H}_{2} \mathrm{O}$ and PCR amplified with previously described primers AJ75 (5'-CGTATTCACGGCTTCGCAGAT-3') and AJ76 (5'-ACCCGCCAGGATAGTCGCATA-3') (McManus and Jones 1995). PCR assays, $25 \mu \mathrm{l}$ in volume, consisted of $12.3 \mu \mathrm{l}$ of $\mathrm{H}_{2} \mathrm{O}, 5 \mu \mathrm{l}$ of $5 \times$ Green GoTaq Flexi Buffer (Promega Corp., Madison, WI), $1 \mu 1$

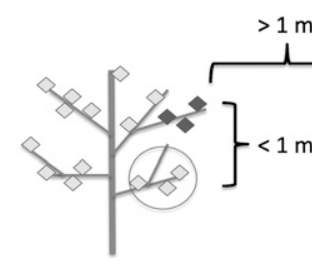

Center point tree ' $c p^{\prime}$

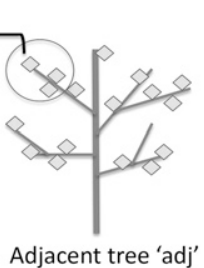

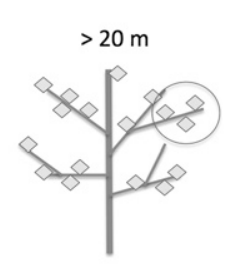

Fig. 1. Representation of the budwood stick collection practices for three fire blight proximity ranges, where asymptomatic budwood sticks were collected either on the center-point tree with fire blight symptoms (cp), from branches on trees adjacent to the center-point tree (adj), and from a trees more than $20 \mathrm{~m}$ from the symptomatic center-point tree $(>20 \mathrm{~m})$. Diamonds represent leaves, with pale-gray diamonds indicating healthy leaves and dark-gray diamonds indicating fire blight infection. 
each of forward and reverse primer, $0.5 \mu \mathrm{l}$ of $10 \mathrm{mM} \mathrm{dNTP}$ mix (Promega Corp.), $2.5 \mu \mathrm{l}$ of $25 \mathrm{mM} \mathrm{MgCl}_{2}$ (Promega Corp.), $0.2 \mu \mathrm{l}$ of GoTaq G2 Flexi DNA Polymerase (Promega Corp.), and $2.5 \mu \mathrm{l}$ of bacterial suspension sample. Cycling parameters consisted of $5 \mathrm{~min}$ at $94^{\circ} \mathrm{C}$; followed by 35 cycles of denaturation at $94^{\circ} \mathrm{C}$ for $30 \mathrm{~s}$, annealing at $52^{\circ} \mathrm{C}$ for $30 \mathrm{~s}$, and extension at $72^{\circ} \mathrm{C}$ for $30 \mathrm{~s}$; followed by a final extension at $72^{\circ} \mathrm{C}$ for $7 \mathrm{~min}$. PCR products were separated using gel electrophoresis with $1 \%$ agarose gels in $1 \times$ Tris-borate-EDTA buffer $(44.5 \mathrm{mM}$ Tris-borate and $1 \mathrm{mM}$ EDTA, $\mathrm{pH} 8.0$ ) at $90 \mathrm{~V}$ for $60 \mathrm{~min}$. PCR products were purified for subsequent sequencing using a Zymo DNA Clean \& Concentrator kit (Zymo Research, Irvine, CA). Purified products were sequenced at the Cornell Biotechnical Resource center in Ithaca, NY using an ABI 3730xl capillary electrophoresis instrument (Applied Biosystems, Waltham, MA).

Analysis of budwood isolation data. For each of the four seasons (2012 to 2015) and both Gala and Topaz orchards, the incidence of budwood sticks with buds infected by E. amylovora was determined for each of the three fire blight proximity ranges (i.e., center-point, adjacent, and $>20 \mathrm{~m}$ ) in each of the replicate sampling blocks. In 2014 and 2015, total E. amylovora CFU per gram were enumerated from bud isolations, and mean CFU per gram across replicate sampling blocks for each of the three ranges was determined. The effect of proximity to fire blight symptoms on both the incidence of buds infected with E. amylovora and E. amylovora CFU per gram obtained from buds (2014 and 2015 only) was analyzed as a randomized complete block design using Generalized Linear Mixed Models without a link function with the GLIMMIX procedure of SAS (v9.4; SAS Institute, Cary, NC), whereby the proximity ranges were fixed effects and three replicate sampling blocks were random effects. Differences in the mean incidence of infected buds or mean E. amylovora CFU per gram for each of the three ranges were determined using the 'lsmeans' statement of GLIMMIX at the 5\% level of significance (SAS Institute). After analysis, log CFU per gram were calculated to more clearly present results.

\section{Results}

Incidence of $E$. amylovora in asymptomatic budwood. E. amylovora was isolated from buds on budwood sticks collected from commercial orchards in all 4 years from 2012 to 2015. Putative E. amylovora colonies all displayed the characteristic cratered appearance on CG, and representative colonies selected for PCR using primers AJ75 and AJ76 all produced the expected 840-bp band indicative of pEA29. Sequencing of the 840-bp PCR products and subsequent BLAST searches using the National Center for Biotechnology Information (NCBI) GenBank database (http://www.ncbi.nlm.nih. gov) revealed that these products were over $99 \%$ homologous to known sequences for E. amylovora pEA29 (e.g., accession number FN434114).

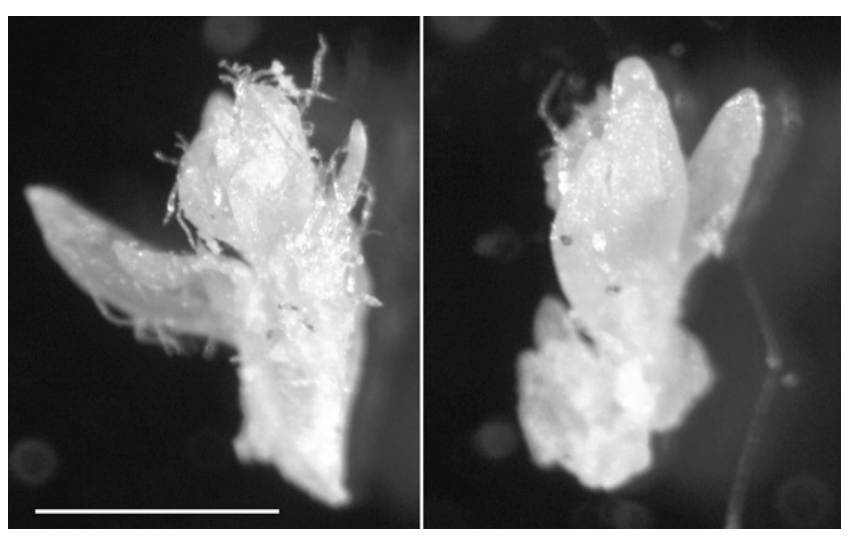

Fig. 2. Example of apple bud dissections after bud scales had been removed by individual dissection needles prior to surface sterilization. Bar in the left panel is $3 \mathrm{~mm}$.
In the Topaz orchard, the mean incidence of E. amylovora in buds was often lower on trees that were further from the center-point trees in all years of this study (Fig. 3). The clear exception to this trend was the 2013 collection, where the incidence of bud infestation on centerpoint and $>20-\mathrm{m}$ trees were nearly identical. In 2012, the mean incidence of E. amylovora in buds on the center-point trees was $40 \%$ compared with $13 \%$ for $>20-\mathrm{m}$ trees. However, those differences were not significant, due to a high variability between replicates. In 2014 and 2015, there were significant differences in the incidence of bud infestation among all three fire blight proximity ranges.

In the Gala orchard, the trend of a lower mean incidence of E. amylovora in buds on trees further from the symptomatic center-point tree was less consistent over the 4 years of the study. In 2012 and 2015, there were significant $(P<0.05)$ differences between the incidence of E. amylovora in buds on the center-point trees $(2012,80 \%$ and $2015,77 \%$ ) compared with $>20-\mathrm{m}$ trees $(2012,33 \%$ and 2015 , 0\%) (Fig. 3). In 2013 and 2014, a lower mean incidence was observed between the center-point tree $(2013,93 \%$ and $2014,100 \%)$ and $>20$-m trees $(2013,60 \% ; 2014,97 \%)$ but these differences were not significant.

Quantification of $\boldsymbol{E}$. amylovora CFU in buds. After observing differences in the incidence of E. amylovora in buds among the three fire blight proximity ranges in 2012 and 2013, E. amylovora CFU were enumerated for collections made from both the Topaz and Gala orchards in 2014 and 2015. Similar to the trend with the incidence of bud infestation, buds on the center-point trees had higher numbers of E. amylovora (CFU) than those from trees further away (adjacent or $>20 \mathrm{~m}$ ). In the Topaz orchard, E. amylovora $\mathrm{CFU}$ in buds ranged from 3.9 to $5.5 \mathrm{log} \mathrm{CFU} / \mathrm{g}$ across all proximity ranges over both years. In 2014 , there were significant differences $(P<0.05)$ in E. amylovora $\mathrm{CFU}$ in buds between the center-point trees $(5.5 \mathrm{log}$ CFU/g) and $>20-\mathrm{m}$ trees ( $4.9 \log$ CFU/g) (Fig. 4). In 2015, there were significant differences $(P<0.05)$ in $E$. amylovora $\mathrm{CFU} /$ liter between all fire blight proximity ranges (Fig. 4). In the Gala orchard, E. amylovora CFU in buds in 2014 ranged from 5.9 to $6.3 \mathrm{log} \mathrm{CFU} / \mathrm{g}$ across all proximity ranges. In 2015, E. amylovora was recovered from buds at 0.0 to $5.4 \log \mathrm{CFU} / \mathrm{g}$, a lower rate than in 2014. In 2014 , there were significant differences $(P<0.05)$ in $E$. amylovora CFU between all fire blight proximity ranges but, in 2015, there were only significant differences $(P=0.00)$ in $E$. amylovora $\mathrm{CFU}$ in buds between center-point or adjacent trees $(5.5 \mathrm{log} \mathrm{CFU} / \mathrm{g})$ and $>20$-m trees (4.9 log CFU/g) (Fig. 4).

Localization of $\boldsymbol{E}$. amylovora within individual buds. Following dissection, removal of the meristematic tissues, and surface sterilization, putative colonies of E. amylovora with a cratered appearance on CG were obtained from all 18 bud meristem dissections. PCR of the colonies using primers AJ75 and AJ76 resulted in the expected $840-b p$ band indicative of pEA29. Sequencing of the 840-bp PCR products and subsequent BLAST searches using the NCBI GenBank database (http://www.ncbi.nlm.nih.gov) revealed that these products were over $99 \%$ homologous to known sequences for E. amylovora pEA29 (e.g., accession number FN434114).

\section{Discussion}

Buds from asymptomatic shoots on Gala and Topaz apple trees from two commercial nursery source plantings were found to harbor the fire blight pathogen E. amylovora. Over 4 years, the incidence of E. amylovora in buds on asymptomatic shoots was often highest for trees with symptomatic tissues and lower on trees further away. At the same time, there was a considerable variability in the incidence of E. amylovora for individual trees in all proximity ranges across all years for both Gala and Topaz orchards. Such variability often overshadowed significant differences that could have been more apparent with a greater number of replicate sampling blocks or greater distance from symptomatic trees. However, the conditions of the proximity ranges and the size of orchard blocks limited the number of replicate sampling blocks to three. In 2012 and 2013, additional sampling was conducted in adjacent orchards of other varieties with no fire blight symptoms within $50 \mathrm{~m}$ of the orchard edge. In these collections, the incidence of E. amylovora in apple buds ranged from 
0 to $10 \%$ (data not shown). Because these trees were of different varieties and outside of the experimental design, they were not included in the study. In regards to variability, one might be tempted to suggest that differences in seasonal weather could have been a factor in variability or, in some instances, uniformly high levels of incidence across all proximity ranges. However, instances of excessive variability or uniformly high levels of bud infestation occurred in different years for the two cultivars (Fig. 3). For example, there was $>95 \%$ incidence of bud infestation for all proximity ranges for the Topaz orchard in 2014 but not the Gala orchard. Variability or uniformly high incidences in bud infestation among treatments could be due to the fact that the symptomatic center-point tree, used as a reference for bud stick collection, may not have been the only source of E. amylovora present in the orchard. Although no additional fire blight symptoms were found, it is possible that small, undetectable cankers from previous seasons' infections served as inoculum sources. It could simply be the case that apple trees within these orchards contained endophytic E. amylovora populations that served as additional cryptic sources of inoculum. Indeed, it is well documented that E. amylovora may live endophytically without producing blight symptoms for several months at a time, and potentially longer, depending on the cultivar and age of the tree (Crepel and Maes 2000; Crepel et al. 1996; Ge and van der Zwet 1996, Keil and van der Zwet 1972; Lelliott 1973; Rosen 1929, 1933, 1936; van der Zwet 1996). Overall, the data from the current study suggest that there may be a relationship between the incidence of bud infestation and proximity to fire blight symptoms. At the same time, there appears to be variability among trees in the level of endophytic E. amylovora in buds. Collecting budwood from trees close to fire blight symptoms may increase the risking of collecting a bud carrying $E$. amylovora.

Little is known about the presence of E. amylovora in apple buds. The phenomena of endophytic E. amylovora in apple buds was first documented by Baldwin and Goodman (1963), who found E. amylovora in dormant buds of 'Jonathan' apple in Missouri. Dueck and Morand (1975) and Bonn (1979) made similar isolations from healthy apple and pear buds, and Calzolari et al. (1982) isolated E. amylovora from imported budwood 10 months prior to identification of the disease in Italy. In the current study, we found asymptomatic infestation of buds to be quite prevalent in two orchards in western New York, a region where fire blight outbreaks are commonly

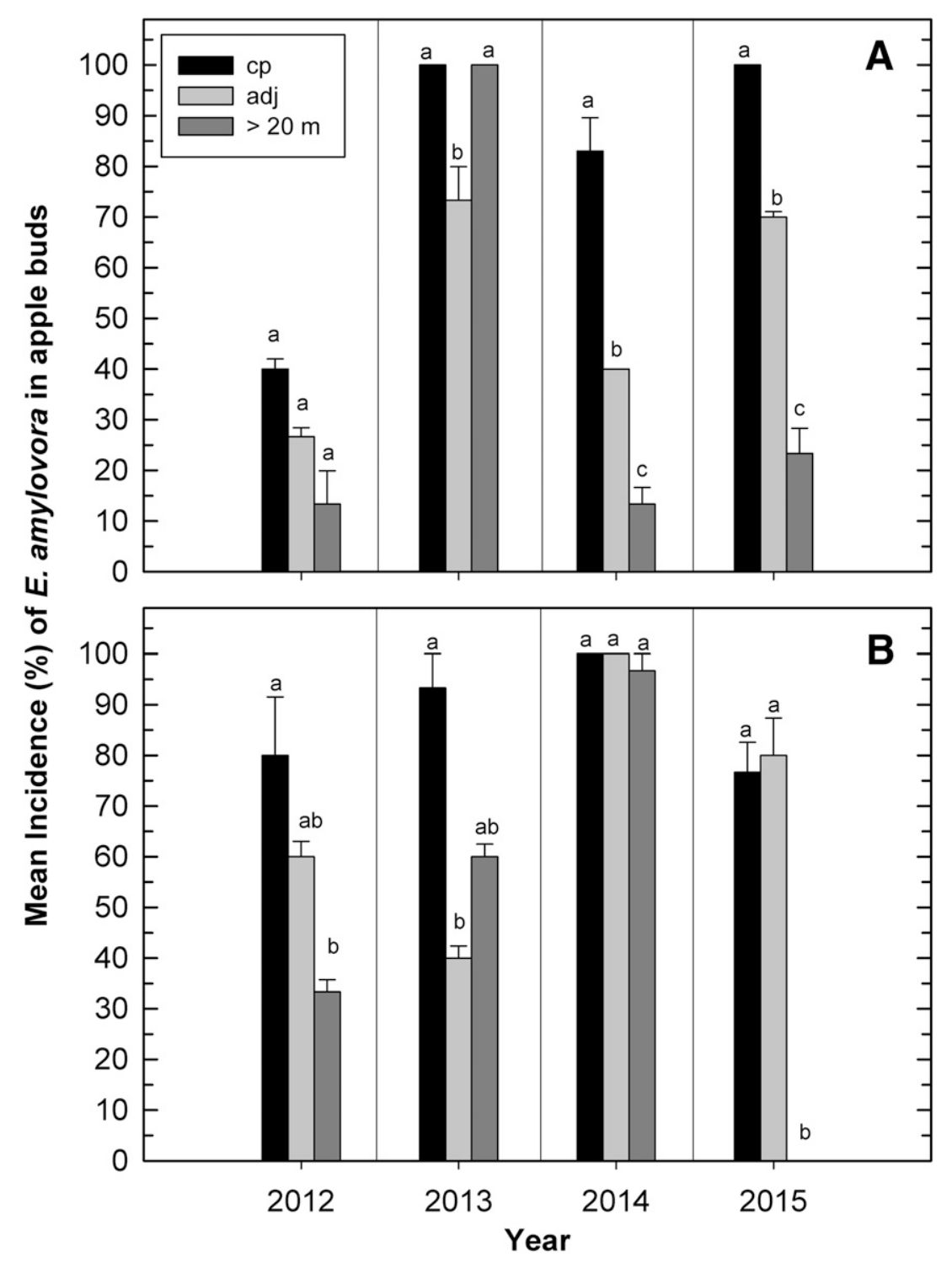

Fig. 3. Incidence of Erwinia amylovora in asymptomatic budwood collected from 2012 to 2015 from three trees at different proximities to a center-point tree with fire blight, where cp represents budwood sticks on the center-point tree less than $1 \mathrm{~m}$ away from fire blight symptoms, adj represents budwood sticks from branches on an adjacent tree that was more than $1 \mathrm{~m}$ from the center-point tree, and $>20 \mathrm{~m}$ represents budwood sticks from a tree $20 \mathrm{~m}$ from the symptomatic center-point tree. Values are the mean and standard error of 10 budwood sticks across three replicate sampling plots for Malus $\times$ domestica A, Topaz and B, Gala. Bars denoted by the same letter are not significantly different at the $5 \%$ level of significance. 
observed. Whether such high levels of bud infestation occur in apple production regions where fire blight rarely occurs has yet to be determined.

In contrast to the early studies simply documenting the recovery of E. amylovora from buds (Baldwin and Goodman 1963; Dueck and Morand 1975), we found that E. amylovora was present beneath bud scales within meristematic tissues. Because E. amylovora was isolated from inner meristematic tissues of buds following rigorous surface sterilization, it may be that bacteria were simply washed into the bud from a source of active infection within the orchard block, or it could be that there are endophytic populations of E. amylovora residing within trees asymptomatically, and these bacteria may move systemically into the bud tissues. Indeed, such an occurrence could explain a lack of a trend between proximity to shoot blight and the incidence of bud infestation. Although the endophytic growth and systemic movement of $E$. amylovora within a tree has been recognized (Crepel and Maes 2000; Crepel et al. 1996; Ge and van der Zwet 1995, 1996; Keil and van der Zwet 1972; Lelliott 1973; Momol et al. 1994, 1998; Rosen 1929, 1933, 1936; van der Zwet 1996), the movement of these bacteria from shoot tissue into the meristem of buds has yet to be established. To definitively demonstrate the movement of E. amylovora from shoots into bud tissues, follow-up studies using microscopy techniques with green fluorescent protein or similarly marked $E$. amylovora strains would be necessary.

Although our bud infestation and, potentially, meristem infestation results may be explained by the systemic internal movement of E. amylovora, our data on the abundance (CFU/liter) of E. amylovora found in buds suggest that visible shoot blight may be a source of external inoculum for bud infestation. In 2014 and 2015, there was a clear trend of higher CFU/liter of E. amylovora in buds with increasing proximity to trees with fire blight symptoms. It may be that the increased presence of E. amylovora in these buds is a direct result of the active inoculum from nearby shoot blight. Alternatively, it may be that active shoot blight is simply an indicator of high levels of endophytic E. amylovora, because some form of weather-related trauma (e.g., thunderstorm) would be needed in order for such
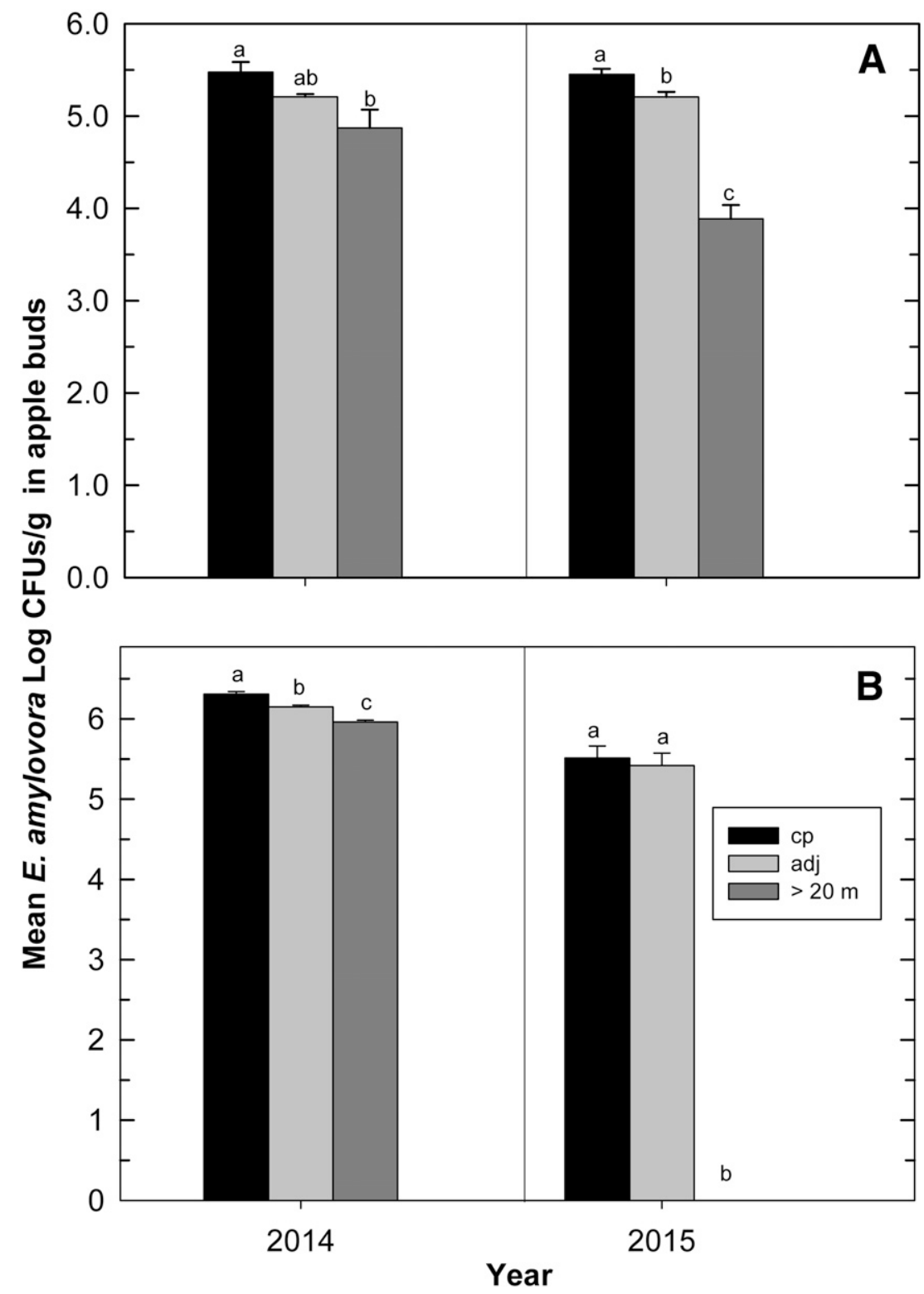

Fig. 4. Erwinia amylovora CFU per gram recovered from asymptomatic budwood collected from 2012 to 2015 from three trees at different proximities to a center-point tree with fire blight symptoms, where $\mathrm{cp}$ represents budwood sticks on the center-point tree less than $1 \mathrm{~m}$ away from fire blight symptoms, adj represents budwood sticks from branches on an adjacent tree that was more than $1 \mathrm{~m}$ from the center-point tree, and $>20 \mathrm{~m}$ represents budwood sticks from a tree $20 \mathrm{~m}$ from the symptomatic center-point tree. Values are the mean and standard error of 10 budwood sticks across three replicate sampling plots for Malus $\times$ domestica A, Topaz and B, Gala. Bars denoted by the same letter are not significantly different at the $5 \%$ level of significance. 
external shoot blight inoculum to contribute to infection. Although this trend of higher CFU of E. amylovora in buds closer to fire blight symptoms was observed in both cultivars, there were differences between the two cultivars. In both years, the number of CFU/liter recovered from Gala buds was much higher than those for Topaz buds. These results suggest that cultivars may differ in their ability to support endophytic populations of E. amylovora in their buds tissues. Moreover, the influence of the rootstock's susceptibility to fire blight may influence the scion's ability to harbor fire blight. However, additional controlled studies would be required to elucidate the contributions of internal and external infection of buds and the relative potential for different cultivars to support endophytic populations of E. amylovora in their buds.

In summary, our studies highlight the ineffectiveness of apple budwood selection protocols for the clonal propagation of trees. Clearly, avoiding symptomatic trees is of the utmost importance when selecting budwood; however, there is a risk of endophytic E. amylovora in buds regardless of distance from these trees. Although trends suggest that there are lower incidences and populations of E. amylovora in trees $20 \mathrm{~m}$ from a symptomatic tree, this does not guarantee the propagation of pathogen-free trees from these materials. Future studies are needed to determine the mechanism of bud infestation and determine the outcomes from using infected budwood in the propagation of apple trees. Of particular importance is investigation of the relationship between endophytic population size and subsequent infection of newly propagated trees.

\section{Acknowledgments}

This research was supported, in part, by funding from state, federal, and institutional funds appropriated to the New York State Agricultural Experiment Station, New York State IPM, New York State Department of Agriculture \& Markets-Specialty Crop Block Grant Program, and the Apple Research and Development Program.

\section{Literature Cited}

Agnello, A. M., Gardner, R., Helms, M., Landers, A. J., Cox, K. D., Carroll, J. E., Robinson, T. L., Breth, D., Kain, D., Bellinder, R., Curtis, P., and Cheng, L. 2016. Pest management guidelines for commercial tree fruit production 2016. Cornell Cooperative Extension, New York State Agricultural Experiment Station, Geneva.

Baldwin, C. H., and Goodman, R. N. 1963. Prevalence of Erwinia amylovora in apple buds as detected by phage typing. Phytopathology 53:1299-1303.

Bereswill, S., Pahl, A., Bellemann, P., Zeller, W., and Geider, K. 1992. Sensitive and species-specific detection of Erwinia amylovora by polymerase chain reaction analysis. Appl. Environ. Microbiol. 58:3522-3526.

Bonn, W. G. 1979. Fire blight bacteria in symptomless dormant apple and pear buds. Can. J. Plant Pathol. 1:61-62.

Breth, D. I. 2008. Managing fire blight in new apple plantings. N. Y. Fruit Q. 16:9-11.

Calzolari, A., Peddes, P., Mazzucchi, U., Mori, P., and Garzena, C. 1982. Occurrence of Erwinia amylovora in buds of asymptomatic apple plants in commerce. Phytopathol. Z. 103:156-162.

Chiou, C. S., and Jones, A. L. 1993. Nucleotide-sequence analysis of a transposon (Tn5393) carrying streptomycin resistance genes in Erwinia amylovora and other gram-negative bacteria. J. Bacteriol. 175:732-740.

Crepel, C., Geene, J., and Maes, M. 1996. The latent survival of Erwinia amylovora in hibernating shoots. Acta Hortic. 411:21-26.

Crepel, C., and Maes, M. 2000. Hibernation of the fire blight pathogen Erwinia amylovora in host plants. Meded. Fac. Landbouwkd. Toegepaste Biol. Wet. (Univ. Gent) 65:19-25.

Crosse, J. E., and Goodman, R. N. 1973. A selective medium for and a definitive colony characteristic of Erwinia amylovora. Phytopathology 63:1425-1426.

Dueck, J., and Morand, J. B. 1975. Seasonal changes in the epiphytic population of Erwinia amylovora on apple and pear. Can. J. Plant Sci. 55:1007-1012.
Ge, Q., and van der Zwet, T. 1995. Persistence and recovery of endophytic Erwinia amylovora in apparently healthy apple tissues. (Abstr.) Phytopathology 85:630.

Ge, Q., and van der Zwet, T. 1996. Persistence and recovery of endophytic Erwinia amylovora in apparently healthy apple tissues. Acta Hortic. 411:29-34.

Keil, H. L., and van der Zwet, T. 1972. Recovery of Erwinia amylovora from symptomless stems and shoots of Jonathan apple and Bartlett pear trees. Phytopathology 62:39-42.

Korba, J., Sillerova, J., and Kudela, V. 2008. Resistance of apple varieties and selections to Erwinia amylovora in the Czech Republic. Plant Prot. Sci. 44: 91-96.

Lelliott, R. A. 1973. Dose-response experiments on infection of apple plants. Page 937 in: 2nd Int. Congr. Plant Pathol. Abstr.

McGhee, G. C., and Jones, A. L. 2000. Complete nucleotide sequence of ubiquitous plasmid pEA29 from Erwinia amylovora strain Ea88: Gene organization and intraspecies variation. Appl. Environ. Microbiol. 66: 4897-4907.

McGhee, G. C., and Sundin, G. W. 2011. Evaluation of kasugamycin for fire blight management, effect on nontarget bacteria, and assessment of kasugamycin resistance potential in Erwinia amylovora. Phytopathology 101:192-204.

McGrath, M. J., Koczan, J. M., Kennelly, M. M., and Sundin, G. W. 2009. Evidence that prohexadione-calcium induces structural resistance to fire blight infection. Phytopathology 99:591-596.

McManus, P. S., and Jones, A. L. 1994. Role of wind-driven rain, aerosols, and contaminated budwood in incidence and spatial pattern of fire blight in an apple nursery. Plant Dis. 78:1059-1066.

McManus, P. S., and Jones, A. L. 1995. Detection of Erwinia amylovora by nested PCR and PCR-dot-blot and reverse-blot hybridizations. Phytopathology 85 : 618-623.

McManus, P. S., Stockwell, V. O., Sundin, G. W., and Jones, A. L. 2002 Antibiotic use in plant agriculture. Annu. Rev. Phytopathol. 40:443-465.

Momol, M. T., Momol, E. A., Norelli, J. L., Gustafson, H. L., Cummins, J. N., and Aldwinckle, H. S. 1994. Internal spread of Erwinia amylovora through symptomless apple scion tissues into the rootstock. (Abstr.) Phytopathology 84:1373.

Momol, M. T., Norelli, J. L., Piccioni, D. E., Momol, E. A., Gustafson, H. L., Cummins, J. L., and Aldwinckle, H. S. 1998. Internal movement of Erwinia amylovora through symptomless apple scion tissues into the rootstock. Plant Dis. 82:646-650.

Rosen, H. R. 1929. The life history of the fire blight pathogen, Bacilus amylovorus, as related to the means of overwintering and dissemination. Ark. Agric. Exp. Stn. Bull. 244.

Rosen, H. R. 1933. Further studies on the overwintering and dissemination of the fire blight pathogen. Ark. Agric. Exp. Stn. Bull. 283.

Rosen, H. R. 1936. Oversummering of fire-blight pathogen, spraying for control of fire blight, and abscission induced by Erwinia amylovora and Phytomonas syringae. Ark. Agric. Exp. Stn. Bull. 331.

Rosenberger, D. 2003. Susceptibility of new apple cultivars to common apple diseases. N. Y. Fruit Q. 11:17-22.

Smith, T. J. 2002. The three-season evolution of a fire blight outbreak in a nursery using an asymptomatic apple budwood source contaminated with Erwinia amylovora. Acta Hortic. 590:109-113.

Sundin, G. W. 2014. Fire blight. Pages 87-89 in: Compendium of Apple and Pear Diseases and Pests, 2nd ed. T. B. Sutton, H. S. Aldwinckle, A. M. Agnello, and J. F. Walgenbach, eds. American Phytopathological Society, St. Paul, $\mathrm{MN}$.

van der Zwet, T. 1983. Occurrence of fire blight in commercial pear seedling rootstocks following budding with symptomless scionwood. (Abstr.) Phytopathology 73:969.

van der Zwet, T. 1996. Presence of Erwinia amylovora in apparently healthy nursery propagating material. Acta Hortic. 411:127-130.

van der Zwet, T., Orolaza-Halbrendt, N., and Zeller, W. 2012. Pages 37-44 and 305-332 in: Fire Blight History, Biology, and Management. American Phytopathological Society, St. Paul, MN.

Vanneste, J. L., ed. 2000. Fire Blight: The Disease and Its Causative Agent, Erwinia amylovora. CABI Publishing, Oxon, UK.

Yoder, K. S., Miller, S. S., and Byers, R. E. 1999. Suppression of fireblight in apple shoots by prohexadione-calcium following experimental and natural inoculation. HortScience 34:1202-1204. 